\title{
Social Construction of Trust in The Investment of "Bodong"
}

\author{
$\operatorname{Damsar}^{1 *}$, Indrayani ${ }^{2}$ \\ ${ }^{1}$ Department of Sociology, University of Andalas \\ Email: damsar_aziz@yahoo.com \\ ${ }^{2}$ Department of Management, University of Batam
}

\begin{abstract}
This paper aims to explain how trust is constructed in the investment of "bodong" in Indonesia. Investment of "bodong" is the emic concept of Indonesian business community about investment with Ponzi scheme. The growth of "bodong" investment occurred in a legal and socio-political settings where absence of regulation, literacy and oversight of financial services activities, as well as the transition from a controlled democracy to a liberal democracy. The social construction of trust in "bodong" investment is the result of the interrelation between the strategy of the trustee and the trustor's motivation. The trustee strategy includes the use of the effects of reference groups, bonuses, advertisements and charity activities displayed. The majority of trustor did not understand about this investment. The trustor's motivation includes very high profits, the influence of reference groups, attractive bonuses and charity displayed by trustee.
\end{abstract}

The small group of trustors who have understood this type of investment, the opposite is true, the distrust of "bodong" investment is deconstructed by doubts about their own knowledge and understanding because it is different from the reality faced and the speculative behavior they have. Therefore, policies on increasing the literacy of financial investment and banking in the community and supervision of business activities are needed. This paper is produced from qualitative research on 50 informants that gathered by snowball sampling method. The primary data was collected through in-depth interviews. While secondary data were gathered through online media news and documents from related offices. The data were analyzed by using model from Miles and Huberman.

Type of paper: Empirical

Keywords: Investment, Ponzi Scheme, Social Construction, Trust

\section{Introduction}

Trust is an important thing in people's lives. Life does not work when there is no trust (Bok, 1979; Barber, 1983; Seligman, 1997; Sztompka, 1999). In economy, for example, business activity requires trust to make it work (Coleman, 1990). When a business relationship between 
two parties wants to be woven, there needs to be a mutual trudt, i.e. between trustor and trustee. Any investment that will be made by a person or a company to a product requires a certain level of trust. The investor must convince that he/she will earn a profit on what he/she invests in, considering the data, facts and assumptions which lead him/her to be certain. However, there are a lot of investors who feels disappointed of the earnings they got. Some of them misjudged an investment so stuck in the investment of "bodong". Consequently, they incur losses.

According to The Great Dictionary of the Indonesian Language of the Language Center (KBBI), the words "investment" and "bodong" have different meaning. Investment means investing money or capital in a company or project for obtaining profit, while "bodong" means "bulging center" (in Javanese) or strong wind (archaic or unusual) (KBBI). If the words "investment" and "bodong" are combined, then the phrase "investment of bodong" will be "planting of money or capital in a company or project that pops its center or is blustery".

Conversely if the word "bodong" to be translated according to the slang dictionary, the meaning of "investment and "bodong" become harmonious since "bodong" in the slang dictionary means goods which ownership are unknown. Hence, through the combined meanings of KBBI and Slang Dictionary, the phrase "investment of bodong" means the planting of money or capital in a company or project that is not clear or unknown ownership.

The Director of Development of Education Policy and Consumer Protection at the Financial Services Authority (OJK) mentioned six characteristics of investment of bodong. First, the unavailability of a business license, or a business license which is not in accordance with the business activities undertaken. Second, the profits promised to the investors are very large or unnatural. Yields are promised in very high and fixed amounts, and offered at over 5\% a month, which equals to $60 \%$ a year. Third, the investments were offered through internet / online or recruitment of chain-based customers, known as member get member. Fourth, the business domicile is unclear. Even if there is an office space, it is usually for financial administration only. Fifth, the investors and the company cannot make a physical interaction. The investment and recruitment were done via the internet and chain-based customers. Sixth, there is no object of investment. If there are goods, then the price of the goods is not fair when compared with similar goods sold in the real market (aktualita.co, 2014; okezone.com, 2014; kompas.com, 2014; finansial.bisnis.com, 2014)

In the Indonesian business community, investment of bodong is an emic concept of investment with Ponzi scheme. The history of investment of "bodong" can be linked to the business history of Carlo Pietro Giovanni Guglielmo Tebaldo Ponzi, known by the name of Charles Ponzi. He was an Italian immigrant who graduated from the University of Rome La Sapienza and was suspected as one of the main successors in the investment of "bodong". He moved to Boston in 1920 and brought the Postal Reply Coupons (PRC), a special coupon product that could be traded as a worldwide stamp replacement. PRC serves as a replacement for postage stamps for international mail and goods and can be cashed. The price of PRC is higher in Europe than in the US. Recognizing the opportunity of PRC as a promising commodity, he started to buy PRC in Italy and sold it in America.

To fulfill his ambitions of earning great profits, he founded The Security Exchange Company (1920) in Boston and raised public funds through a high commission agent with a $50 \%$ profit pledge within 45 days and $100 \%$ profit for 90 days to invest in the coupon it sells (Frankel, 
2012; Dunn, 2004; Zuckoff, 2005). Since the beginning, Ponzi's idea has failed. This is because the amount of investment is not comparable with the outstanding PRC. Meanwhile, PRC itself is not traded in large quantities. Therefore, he looked for a way out with a new idea which now is known as the Ponzi Scheme. At first, nobody noticed the oddity of the business, owing to the fact that the number of investors kept increasing. The funds from new investors can cover interest payments to old investors, and most of the investors do not take interest from the investment, but instead they replant it. This scheme is known as the Ponzi scheme (Wikipedia. org).

In the Indonesian business history of investment of "bodong", there are at least 10 cases of investment that shake the Indonesian business community because of the amount of investment value and the number of people who became victims: Qurnia Subur Alam Raya, Add Farm, Koperasi Langit Biru, Sarana Perdana Indoglobal, Wahana Global Bersama, Gama Smart, Virgin Gold Mining Corporation, Pohon Mas, Gradiasi Anak Negeri, and CV Sukma Semarang.

Qurnia Subur Alam Raya involved investors totaling 6,800 people and / or institutions with total investment of 467 billion; Add Farm associated with investors amounted to 8,500 people with an investment of 544 billion; Koperasi Langit Biru had 115,000 investors and an investment amount of about 6 trillion; Sarana Perdana Indoglobal included 3401 investors with an estimated investment of about 1.5 to 3 trillion; Wahana Global Bersama was linked to 11,500 investors with investment value ranging from 3.5 to 7 trillion; Gama Smart covered a total of 10,000 investors and with an investment of around 12 trillion; Virgin Gold Mining Corporation involved 40,000 investors with an investment of around 500 billion; Pohon Mas associated with 24,398 investors who invested around 574.10 billion; Gradasi Anak Negeri covered about 21,000 people with an investment of about 390 billion; CV Sukma Semarang had approximately 40,000 customers and an investment of 28 billion.

Interestingly, even though the cases of investment of "bodong" have been widely reported on various mass media, it is still managed to get investors. Therefore, regarding this issue, this paper aims to answer several questions. First, how is the development of the investment of "bodong" in Indonesia? Second, what is the strategy of the company so that people can trust and want to invest in the company. Third, what made the investors believe that the company can be trusted?.

\section{Literature Review}

In the words of Torsvik (2000), trust is "a certain behavioral tendency that can reduce the risk arising from his behavior". The concept of trust associated with risk is also expressed by Luhmann $(1979,1986)$, a term that appears only in modern times. The notion of trust associated with risk is criticized by some theorists, one of whom is Giddens (2005). According to Giddens (2005: 44) trust is basically bound, not to risk, but to various possibilities. Trust always contains the connotation of conviction during all possible consequences, whether it is related to the actions of individuals or with the operation of the system. In the case of trust in human agents, the notion of trust involves "kindness" (appreciation) or love. That is why trust in a person psychologically contains consequences for an individual who believes: moral hostage to good luck is surrendered. However, Giddens (2005) states that trust has its limit. He defined trust as a belief in a person's or system's reliability, in terms of results or events, 
in which the belief expresses a faith to the integrity or love of others, or to the accuracy of the abstract principle (technical knowledge).

The definition of trust that is not associated with risk, is also expressed by Zucker (1986). He sets the boundaries of trust as "a set of expectations shared by all who are in exchange". His definition is close to the limits given by Lawang. According to Lawang (2004: 36), belief is "a relationship between two or more parties that hold hope that benefits one party or both parties through social interaction". Furthermore, he concludes that there are three core concepts of trust. First, social relations between two or more people. Included in this relationship is the institution, which in this sense is represented by people. Second, expectations to be contained in the relationship, which, if realized, will not harm either or both parties. Third, interactions that allow relationships and expectations to materialize.

Of all the definitions above, in this paper, it is more appropriate to use the limits given by Giddens. In addition to covering various phenomena and events of belief, it also has wedges with some other theoretical opinions such as Zucker and Lawang, for example.

How does the interpretation of something so that it can be trusted? To understand this is used the theory of symbolic interactionism of Blumer (1969). In his point of view, there are three premises on which the theory of symbolic interactionism is used. First, man acts on something based on the meanings that exist in them for them. Human action against something happens when something has meaning or meaning to the actor (actor). How an actor acts on something, depending on what meaning or meaning the actor gives to that thing. Second, meaning comes from one's social interaction with others. Through social interaction between individuals, meaning is built. In other words, meaning does not come from the heavens, but is formed or built in the process of interaction between someone with others. Third, these meanings are perfected during the process of social interaction takes place. A meaning is changed, refined or maintained during the social interaction process.

Trust, therefore, is socially constructed (Berger and Luckmann, 1990). It means that trust arises, grows, flowers or disappears in a social interaction (Damsar and Indrayani, 2015; Lawang, 2004). When the actors have established a trust about something (externalization), then something, over time, will become an objective reality (objectification). The reality will be a reference in behaving for the next generation through internalization.

(Vitaly Alexeev M. D., 2016)

\section{Research Methodology}

This study utilized a qualitative approach. The primary data was collected through in-depth interviews with informants who did business in investment of "bodong". It was not easy to get informants who want to open any "disgrace", because they felt ignorant as well as embarrassed to acknowledge their involvement in the investment of bodong. Therefore, only 20 out of 50 informants who have ever done business with investment of bodong. Most of the informants stated that they have never been involved in the investment of bodong, but they know people who have done it.

For the process of interview, the authors used an interview guide that contains several key questions to answer research questions. While secondary data gathered through online media news and documents from related offices, such as the Financial Services Authority (OJK). 
The data were then validated by using two techniques, namely triangulating the source and performing triangulation techniques. The data were analyzed by employing model from Miles and Huberman (1994) which consists of data reduction, display data, and conclusion drawing / verification.

\section{Result}

\subsection{History of the Development of Investment of "Bodong" in Indonesia}

The practice of investment of "bodong" which was first revealed extensively in Indonesia is the case of Jusup Handojo Ongkowidjaja through Yayasan Keluarga Adil Makmur (YKAM), which he founded in 1987 in Jakarta. YKAM was engaged in a lend-borrowing business which was offering a credit package of IDR 5 million without strict requirements and conditions, namely registration fee of IDR 50 thousand and savings deposit of IDR 30 thousand seven times per month. While the loan repayment of IDR 5 million can be repaid for 15 years. Even the borrower (debtors) promised a bonus of IDR 9.6 million when it is paid off. This offer attracted many people to become a member of YKAM, where until February 1988 it reached more than 44,000 people with 70,000 registered packages. Ongkowidjaya's "bodong" investment business went bankrupt when YKAM was not able to withdraw the credit package that had matured, which is about 291 credit packages totaling more than IDR 1 billion, while at that time money in cash only IDR 30 million.

Subsequently, various companies engaged in business practices of "bodong" investment in Indonesia, among others: PT Multi Jaya Indovesco (1992), PT Suti Kelola (1992), Arisan Danasonik (1995), PT Banyumas Mulya Abadi (1996), Kospin (1998) Yoshihiro (1998), PT Era Catur Wicaksana or New Era 21 (1999), PT Inter Jasa Perkasa (1999), Citra Keluarga Sejahtera Sentosa (1999), Happy Growing Young or Higam Net (1999), PT Rosindo (1999) PT Promet (2000), PT Probest International (2000), PT Qurnia Subur Alam Raya (2001), YAMI (2002), PT Goldquest (2003), Golden Saving (2003), PT Adess Sumber Hidup Dinamika (2003), IBIST (2007), TV1 Express (2011), and more.

In the history of surveillance of financial services in Indonesia, the precautionary measures and supervision of investment of "bodong" were first performed on November 7, 2014 by the Financial Services Authority (OJK). The agency announced publicly and massively through OJK and quoted by various online media, about the alleged 262 companies in Indonesia who have committed fraud under the guise of investment. 218 out of 262 companies are unlicensed investment offerings from the authorities, while the remaining 44 are related to the authority of several agencies such as the Ministry of Cooperatives and Micro, Small Medium Enterprises, the Commodity Futures Trading Supervisory Agency, the Ministry of Industry and Trade and the Ministry of Justice and Human Rights.

\subsection{Strategies for Making Trust}

Trust in the investment of "bodong" is constructed intentionally (by design) by the trustee. To acquire trust from the community, there are several strategies undertaken by trustee, including the use of the influence of reference group, bonuses, and social worship or charity.

Reference group isa group that people refer to when evaluating their own qualities, circumstances, attitudes, values and behaviors (Thompson and Hickey, 2005). It is a group that become a 
reference or identification of a person in doing something. Reference groups that are often used as self-identification for a person to decide can vary are community leaders, celebrities, and experts. Community leaders are prominent people, usually in the areas of politics, religion, and custom. Their personality is a community reference in doing things, including business activities.

The ability of business people to bind the public leaders in a network or as a mouth piece of business interests has a positive impact on society's view. The public considers that many great people or public leaders are with them so that society deserves to trust them. That is why many business people are binding on political, religious, and indigenous leaders to join their business activities. The more numerous and diverse public leaders who join a network of business groups, the higher the degree of trust gained from the community. Therefore, advertisements of investment of "bodong" that display photos of high-ranking state officials attending the inauguration of headquarters, for example, will generate trust if they have not yet emerged or established trust if they are still faltering.

The same is true of celebrities. Since celebrities are public figures, they have the same influence on audiences as the political leaders. They are public figures. Audiences are influenced by celebrities not because they have religious competence as well as those of religious leaders, or about customs such as adat leaders, but because of their idiocy. Business people understand that people view celebrities as unlikely to trade their fools with a price. It is understood by the public that it will result in waning of celebrity fools. Therefore, people perceive that celebrity is more careful in giving trust. This view is used by businesses to attract celebrities to invest in their business.

Experts are trusted by their suggestions or reviews because they have capabilities and competencies in their fields. If a financial expert, for example, provides recommendations to audiences, as a potential investor, to an investment firm that the company's stock is prospective, then the audience will seriously consider the recommendation. At the local community level, experts are associated with work in education such as teachers or lecturers. The views of teachers or lecturers about something, including about an investment, to a certain degree are believed to be true by the local community. Therefore, when a teacher or lecturer is successfully recruited by the company of "bodong" investment as an investor, it is likely that he or she has successfully recruited many community members into investors.

Giving bonuses is a form of engineering diversion of the focus of attention from major to minor, from the main to the periphery, or from the important to the trivial. Giving bonuses is a smart strategy for focus shifting, so that the prospective customers are preoccupied with the flow of information of various "instant profits" gained when they want to become customers at the investment of "bodong". This business causes them to be unconcerned about deceit or fraud from the investment of "bodong".

Giving bonuses in the form of goods (motorcycles, cars, and others), money transfers in accounts, or on holiday to favorite tourist attractions are engineered in interesting publications. Impressions in the form of pictures, testimonials, and videos about giving bonuses conceal the lies that accompany them. Marketing officers are trained in such a way that it has the expertise to distract prospective customers from important things to unimportant ones when there is a chance to meet face-to-face. When the investment of "bodong" take Multi-Level Marketing system, then the downline will take the role of the marketing officer. 
Companies from investment bodong who have business units in a region tend to utilize its presence in the location as a means of promotion. Therefore, the company conducts various charitable activities such as providing compensation to poor families, mass circumcision, and others. In addition, they use local labor as a lowly employee of their company. These lowly employees are also indirectly a safeguard for their business.

\subsection{Reasons for Investing}

The first question asked to the research informants is whether they know about the investment of "bodong". From 50 informants who were studied, $80 \%$ said they do not know, while the remaining $20 \%$ said that they aware about this type of investment. Ignorance about the investment of "bodong" is utilized by the company of "bodong" investment to influence the prospective customers or investors. As mentioned above, the trust is constructed by the trustee in various ways, including using the reference group, providing various bonuses, and linking the investment business with charity.

On the question of "what is the reason you do business in the investment bodong", all informants acknowledge that a very high return compared to other businesses is their main reason. Moreover, $60 \%$ of informants replied that they were involved in the business because of the influence of relatives and close friends. There are $50 \%$ of informants interested in investing because of the bonus given. While the effect of advertising amounted to $40 \%$. In the meantime, the informants who were influenced by community leaders amounted to $30 \%$.

What causes people to know about the investment of "bodong", but they are still investing in a company of "bodong" investment? From the results of in-depth interviews, those who already know about investment of "bodong" was not yet understand the business. Their understanding was shaken by the influence of relatives or close friends who have gained the immediate benefits of this investment, that is in the form of additional money flowing from investment into account, holiday bonus, and other vouchers.

\section{Discussion}

Starting from the history of the development of investment of "bodong" in Indonesia seen that investment of "bodong" grow and develop in situation of regulation and supervision to the activity of financial services in banking sector, capital market sector and non-bank financial industry sector very weak, even almost nothing, especially to industrial sector non-bank finance (Bambang, 2013; Mantulangi, 2017). This can be seen from the many cases that appear on the surface, from 1988 to 2016. This reality would be a fertile place for the flowering of distrust in society (Sztompka, 1999; Warnock, 1971; Banfield, 1967).

Another interesting finding is the most horrendous case of Indonesian people in the period 1998 to 2003, which is now known as the transition period. At the time, there was a change of the controlled democratic system toward a liberal democracy. The transition atmosphere caused euphoria and uncertainty. The society experienced euphoria because it was free from various social and political controls in the past (New Order Era), so feel able to do things that previously cannot or taboo to do. On the other hand, at the same time people were experiencing uncertainty, especially related to economic life. At that time, many companies went bankrupt and workers or employees experienced termination of employment. Hence, an offer of a high 
profit was considered as a smart solution to the uncertainty in economic life. This transitional period is called by Durkheim (1951) as an anomie. In the condition of anomie, various social rules regulating human conduct, as well as agencies enforcing obedience, are in disarray (Sztompka, 1999: 122). This makes social life more problematic, insecure, unorderly, and unpredictable (Durkheim, 1951; Merton, 1996; Sztompka, 1999).

Such socio-political economic setting, the trust in the investment of "bodong" is constructed (Berger and Luckmann, 1990). In addition, the lack of regulation, the condition of anomie, and the absence of oversight bodies also become the legal setting in social construction of trust in the investment of "bodong". Furthermore, the institutional vacuum, in turn, causes institutions that educate on finance and investment does not exist. As a result, there are only $20 \%$ who understand about investment of "bodong". So, there are $80 \%$ of informants doing business in investment of "bodong" because of ignorance. These circumstances can have an impact on the damage of the psychological propensity to be trustful (Sztompka, 1999), of "basic trust" (Giddens, 1991), of "capacity for trust" (Hardin, 1993), of "innate sociability" (Fukuyama, 1995).

The social construction of the trust in investment of "bodong" takes two forms. First, trust is constructed upon ignorance, so they only know the big returns while risks are never imagined. The construction of trust grows stronger when the various influences of the reference group, the lucrative bonus offer, and the influence of advertising accompany the process. When someone is interested in something, which is very profitable, because of ignorance he wants to do business with him. So, when a wife or husband, family, close friends, or community leaders encourage, motivate, or approve of what he is going to do, he will interpret that his actions are right. It can happen because the wife, husband, family, close friends, or community leaders have a reputation and good performance in the view of the actor. Reputation means simply the record of past deeds. While the actual means performance deeds, present conduct, are currently the result (Sztompka, 1999: 71-77). Reputation and performance is the basis on which one determines the primary trustworthiness of targets (Wilson, 1993; Chong, 1992).

In other side, a person's relationship with his wife, husband, family, close friends, and public figures shows the relationship in intimate and familiar conditions. Intimacy and familiarity open access to relevant information and diminish the chances of manipulation and deceit (Sztompka, 1999: 81). The familiarity and closeness are important aspects of social construction of trust (Luhmann, 1979; Hardin, 1993).

Testimony is a signal of reputation (Sztompka, 1999). Trust in a "bodong" investment will be reinforced if someone knows that his/her relative is receiving a return or bonus. This testimony causes him to be more confident in a "bodong" investment. On the other hand, bonus is a meaning to the advantage of an action (Blumer, 1969). When the investor has received a return, he/she becomes more confident in the investment of "bodong". Hence, the likelihood of recommending the business to a friend is high.

Two, the distrust of the "bodong" investment is deconstructed by doubts in the understanding of risk and speculative behavior. Even though some people understand the risks of bodong investments, they feel doubt by the fact that their relatives gained high returns and attractive bonuses from the investments. Moreover, since there is no regulatory framework regarding bodong investment, the doubts grow stronger. This is due to speculative 
behavior, which means that people who have a tendency of speculative behavior do not act based on rationality but rather based on speculation on profit (Weber, 1978 [1922]). In the study, it was found that $20 \%$ of informants fell into this category.

\section{Conclusion}

The root cause of the development of bodong investments in Indonesia are the absence of regulation, literacy and oversight of financial services activities, and the transition from "controlled" democracy to liberal democracy. The social construction of trust in "bodong" investment is the result of the interrelation between the strategy of the trustee and the trustor's motivation. The trustee strategy includes the use of the effects of reference groups, bonuses, advertisements and charity activities displayed. While the trustor's motivation includes very high profits, the influence of reference groups, and attractive bonuses. Hence, based on the results of this study, it is encouraged for the government to make a policy to increase the literacy of financial and banking investment in the community as well as the supervision of business activities.

Future research can explore more regarding the issue of whether the victims of "bodong" investment feel traumatized to be involved again in a financial investment or other similar business In addition, how to prepare tools, procedures or mechanisms as an early warning system against the emergence and/or the existence of "bodong" investment can be studied.

\section{References}

Bambang, M. (2013) "Pranata Hukum Lembaga Keuangan dan Investasi Bodong", In: Value Added, Vol. 9, No. 2, pp. 42-56.

Banfield, E.C. (1967) The Moral Basis of a Backward Society. New York: Free Press.

Barber, B. (1983) The Logic and Limits of Trust. New Brunswick, New Jersey: Rutgers University Press.

Berger, P. L. \& Luckmann, T. (1990) Tafsir Sosial Atas Kenyataan, Risalah tentang Sosiologi Pengetahuan (trans.) Jakarta: LP3ES.

Blumer, H. (1969) Symbolic Interactionism: Perspective and Method. Englewood, N.J.: Prentice Hall.

Bok, S. (1979) Lying: Moral Choice in Public and Private Life. New York: Vintage Books.

Chong, D. (1992) "Reputation and cooperative behavior" in: Social Science Information, Vol.31, No. 4, pp.375-399.

Coleman, J.C. (1990) Foundations of Social Theory. Cambridge: Harvard University Press

Craib, I. (1986) Teori Teori Sosial Modern. Jakarta: Rajawali Press. 
Damsar \& Indrayani (2015) Pengantar Sosiologi Ekonomi. Jakarta: Prenadamedia.

Dunn, D. (2004). Ponzi: The Incredible True Story of the King of Financial Cons (Library of Larceny). New York: Broadway.

Durkheim, E. (1951), Suicide. New York: The Free Press.

Frankel, T. (2012). The Ponzi Scheme Puzzle: A History and Analysis of Con Artists and Victims. USA: Oxford University Press.

Fukuyama, F. (1995) Trust: The Social Virtues and the Creation of Prosperity. New York: The Free Press.

Giddens, A. (1991) Modernity and Self-Identity. Stanford, Calif.: Stanford University Press.

Giddens, A. et all (2005) Sociology : Sejarah dan Berbagai Pemikirannya. (trans.). Yogyakarta: Kreasi Wacana.

Hardin, R. (1993) "The Street-level of epistymology of trust”, in: Politics and Society, Vol. 21, No. 4, pp. 505-529.

Lawang, R.M.Z. (2004) Kapital Sosial dalam Perspektif Sosiologik Suatu Pengantar. Depok: FISIP UI Press.

Luhmann, N. (1979). Trust and Power. Chichester: Willey.

(1986) "Familiarity, confidence, trust: problems and alternatives" in: D. Gambetta (ed.), Trust-Making and Breaking Cooperative Relations”. New York: Basil Blacwell.

Mantulangi, N. (2017) "Kajian Hukum dan Investasi dan Perlindungan Terhadap Korban Investasi Bodong” in: Lex Administratum, Vol. V, No. 1, pp.108-115.

Merton, R.K. (1996) On Social Structure and Science. (ed. by P. Sztompka), Chicago:University of Chicago Press.

Miles, M.B. \& Huberman, A.M. (1994) Qualitative Data Analysis (2nd edition). Thousand Oaks, CA: Sage Publications.

Seligman, A. (1997) The Problem of Trust. Princeton: Princeton University Press.

Simmel, G. (1906/1950) “The Secret and the Secret Society” in: K.H. Wolff(ed.), The Sociology of Georg Simmel. New York: Free Press.

Sztompka, P. (1999) Trust: Asociological Theory. Cambridge: Cambridge University Press

Thompson, W. \& Hickey, J. (2005) Society in Focus. Boston, MA: Pearson.

Torsvik, G. (2000) Social Capital and Economic Development. London: Sage. 
Warnock, G.J. (1971) The Object of Morality. London: Methuen.

Weber, M 1978(1922) Economy and Society: An Outline of Interpretative Sociology. Berkeley: University of California Press

Wilson, J.Q. (1993) The Moral Sense. New York: Free Press.

Zucker, L. (1986) “Production of trust: institutional source of economic structure”, 1840-1920, in: Research in Organisational Behaviour, 8, 53-111

Zuckoff, M. (2005). Ponzi's Scheme: The True Story of a Financial Legend. New York: Random House. 